\title{
International normalized ratio and serum C-reactive protein are feasible markers to predict complicated appendicitis
}

\author{
Maru Kim, Sung-Jeep Kim and Hang Joo Cho*
}

\begin{abstract}
Background: Diagnostic approach for complicated appendicitis is still controversial. We planned this study to analyze preoperative laboratory markers that may predict complications of appendicitis.

Methods: Patients who underwent appendectomy were retrospectively recruited. They were divided into complicated appendicitis and non-complicated appendicitis groups and their preoperative laboratory results were reviewed.

Results: A total of 234 patients were included. Elevated international normalized ratio (INR) and serum C-reactive protein (CRP) were associated with complicated appendicitis $(p=0.001)$. On ROC curve analysis, area under the curve (AUC) of CRP and INR were 0.796 and 0.723 , respectively.

Conclusions: INR and CRP increased significantly in patients with complicated appendicitis. Further studies evaluating INR and CRP in patients undergoing conservative management for appendicitis are required.
\end{abstract}

Keywords: Appendicitis, Complication, C-reactive protein, International normalized ratio, Diagnosis

\section{Background}

Appendicitis is a common disease. Lifetime risk for having appendicitis is reported to be about 7 to $10 \%[1,2]$. Usual management of appendicitis is laparoscopic appendectomy, which has lower complication rate, length of hospital stay, and mortality than open appendectomy [3-5]. However, morbidity or mortality after laparoscopic appendectomy could be happened [6-8].

Many studies analyzing the conservative management of appendicitis have been published. Almost all of these studies looked at managing uncomplicated appendicitis [9-11], including the use of antibiotics in conservative management. No definite method is currently available to distinguish complicated from uncomplicated appendicitis preoperatively, despite the fact that several studies about predicting complicated appendicitis were published $[3,12-15]$. In this study, we tried to utilize preoperative laboratory markers to predict whether appendicitis was complicated or not.

\footnotetext{
* Correspondence: surgeryman@catholic.ac.kr

* Correspondence: surgeryman@catholic.ac.kr of Korea, Seoul, Republic of Korea
}

(c) 2016 The Author(s). Open Access This article is distributed under the terms of the Creative Commons Attribution 4.0 International License (http://creativecommons.org/licenses/by/4.0/), which permits unrestricted use, distribution, and reproduction in any medium, provided you give appropriate credit to the original author(s) and the source, provide a link to the Creative Commons license, and indicate if changes were made. The Creative Commons Public Domain Dedication waiver (http://creativecommons.org/publicdomain/zero/1.0/) applies to the data made available in this article, unless otherwise stated.

\section{Methods}

Institutional review board of Uijeongbu St. Mary's hospital approved this retrospective study and informed consent was waived. Medical records of patients who underwent appendectomy between February 2014 and September 2014 were reviewed. The following data were collected; general characteristics as sex, and age; initial laboratory results including white blood cell counts (WBC), neutrophil percent, serum total bilirubin (TB), serum C-reactive protein (CRP) and international normalized ratio (INR); and perioperative data as operation record, pathologic report, initial body temperature (BT). Hospital stay, and wound complications-defined as pus-like discharge from wound-were checked, as secondary outcomes, to analyze post-operative outcomes. Pathological confirmation of appendicitis was mandatory for inclusion in the study. Patients with other inflammatory conditions such as diverticulitis, pelvic inflammatory disease, torsion of ovary, small bowel perforation and intussusceptions were excluded. Additionally, patients with missing values or after incidental appendectomy were excluded. 
Based on patients' records, perforated appendicitis, periappendiceal abscess, and peritonitis were regarded as complicated appendicitis (CA), whereas other findings were regarded as non-complicated appendicitis (NA). Upper limits for normal WBC, CRP, TB, and INR were specified at $10 \times 10^{9} / \mathrm{L}, 0.3 \mathrm{mg} / \mathrm{dL}, 1.2 \mathrm{mg} / \mathrm{dL}$ and 1.22 , respectively. Body temperature higher than $37.2{ }^{\circ} \mathrm{C}$ was regarded as fever. Type of appendicitis and clinical outcomes were correlated to laboratory results.

Independent $\mathrm{t}$-test was used for quantitative analysis and Chi-square and Fisher's exact test were used for qualitative analysis. P-value of less than 0.05 was regarded as statistically significant. Additionally, receiver operating characteristic (ROC) curve analysis was used to evaluate each marker's accuracy. SPSS version 17.0 (SPSS Inc. Chicago, IL) was used for statistical analysis.

\section{Results}

The medical records of 258 who underwent appendectomy during the period from February 2014 to September 2014 were reviewed. Only 234 patients were eligible for enrollment in the study. Mean age of the patients was $35.8 \pm 18.9$ years and number of male patients was 126. Fifty-four patients had complicated appendicitis and 180 patients had uncomplicated appendicitis.

Results of laboratory markers and other basic characteristics were analyzed according to the type of appendicitis. Statistically significant elevations in CRP and INR were identified in CA patients $(p=0.001)$. In addition, they were associated with a high relative risk (relative risk [95\% confidence interval]: 1.291 [1.149-1.452], and
2.059 [1.032-4.108], respectively). On the contrary, no other associations between type of appendicitis and preoperative WBC, neutrophil percent, or TB were identified. Similarly, BT showed no statistically significant association with the type of appendicitis. These results are shown in Table 1.

ROC curve analysis was performed to examine the feasibility of each parameter. Area under curve (AUC) of CRP and INR was 0.796 and 0.723 , respectively, which showed their feasibility as useful CA predictors. However, AUC of TB was only 0.576, and the other parameters showed similar AUCs that were much lower than those of CRP and INR. Results of ROC curve analysis are summarized in Table 2 and Fig. 1.

Additional analyses of post-operative outcomes, namely hospital stay and wound complications, are summarized in Table 3. Elevated CRP and INR were associated with longer hospital stay ( 3.20 vs. 3.94 days, $p<0.001 ; 3.70$ vs. 4.85 days, $p=0.001$, respectively). However, they did not show a statistically significant association with wound complication.

\section{Discussion}

Several approaches were proposed to diagnose acute appendicitis. There were many studies about computed tomography $(\mathrm{CT})$ scan in evaluation of acute appendicitis that showed its feasibility as a diagnostic method $[16,17]$. However, other studies highlighted the risk from radiation exposure after CT scan [18, 19]. Although the risk of malignancy arising after $\mathrm{CT}$ scan is

Table 1 Characteristics and analysis of patients according to type of appendicitis

\begin{tabular}{|c|c|c|c|c|}
\hline & & $\begin{array}{l}\text { Non-complicated appendicitis } \\
(n=180)\end{array}$ & $\begin{array}{l}\text { Complicated appendicitis } \\
(n=54)\end{array}$ & $p$-value \\
\hline \multirow[t]{2}{*}{ Gender } & Male & $92(51.1 \%)$ & $34(63.0 \%)$ & \multirow[t]{2}{*}{0.125} \\
\hline & Female & $88(48.9 \%)$ & $20(38.0 \%)$ & \\
\hline Age in years (mean $\pm S D)$ & & $34.7 \pm 17.9$ & $39.5 \pm 21.7$ & 0.144 \\
\hline \multirow[t]{2}{*}{ WBC } & Normal & $44(24.4 \%)$ & $11(20.4 \%)$ & \multirow[t]{2}{*}{0.536} \\
\hline & Elevated & $136(75.6 \%)$ & $43(79.6 \%)$ & \\
\hline \multirow[t]{2}{*}{ Neutrophil percent } & Normal & 70 (38.9 \%) & $15(27.8 \%)$ & \multirow[t]{2}{*}{0.136} \\
\hline & Elevated & $110(61.1 \%)$ & $39(72.2 \%)$ & \\
\hline \multirow[t]{2}{*}{ C-reactive protein } & Normal & $52(28.9 \%)$ & $4(7.4 \%)$ & \multirow[t]{2}{*}{0.001} \\
\hline & Elevated & $128(71.1 \%)$ & $50(92.6 \%)$ & \\
\hline \multirow[t]{2}{*}{ Total bilirubin } & Normal & $138(76.7 \%)$ & $37(68.5 \%)$ & \multirow[t]{2}{*}{0.227} \\
\hline & Elevated & $42(23.3 \%)$ & $17(31.5 \%)$ & \\
\hline \multirow[t]{2}{*}{ Body temperature } & Normal & $163(90.6 \%)$ & $50(92.6 \%)$ & \multirow[t]{2}{*}{0.79} \\
\hline & Elevated & 17 (9.4 \%) & $4(7.4 \%)$ & \\
\hline \multirow[t]{2}{*}{ INR } & Normal & $175(97.2 \%)$ & $46(85.2 \%)$ & \multirow[t]{2}{*}{0.001} \\
\hline & Elevated & $5(2.8 \%)$ & $8(14.8 \%)$ & \\
\hline
\end{tabular}


Table 2 Area under curve from receiver operating curve analysis of each parameter

\begin{tabular}{lc}
\hline & Area under curve \\
\hline WBC & 0.594 \\
Neutrophil percent & 0.577 \\
C-reactive protein & 0.796 \\
Total bilirubin & 0.576 \\
Body temperature & 0.552 \\
INR & 0.723 \\
\hline
\end{tabular}

WBC white blood cell counts, INR international normalized ratio

rare and low, however; incorporating CT scan as a routine diagnostic method for appendicitis should be decided carefully, considering the benign nature of the disease.

Many studies looking at the power of CRP in predicting complications of appendicitis have been published recently showing positive results $[20,21]$. Similarly, in the present study, elevated CRP was associated with CA and its AUC was the highest among the tested parameters. The results of the present study support the use of CRP as a predictor for complicated appendicitis.
Interestingly, our study focused on the association between INR and type of appendicitis. To the best of our knowledge, this study was the first to look at this association. Our results showed a statistically significant association between INR and both CA as well as postoperative outcome.

Clotting pathway is activated by inflammatory mediators following exposure to infectious agents like viruses and bacteria, or inflammatory cytokines like interleukin1 , interleukin-6, tissue necrosis factors, etc. [22]. Therefore in severe inflammatory conditions as sepsis, patients are prone to have bleeding tendency, known as disseminated intravascular coagulopathy, caused by excessive consumption of coagulation factors [23]. Prothrombin time is the general test used to check bleeding tendency, especially for the extrinsic pathway, and INR represents a mathematical modification of prothrombin time to allow for standardized reporting between different laboratories. We focused on the association between INR and acute appendicitis as we postulated that CA may be associated with bleeding tendency, despite rarely aggravating to sepsis. For preoperative evaluation, INR is a mandatory parameter to check, while CRP is helpful but not essential.

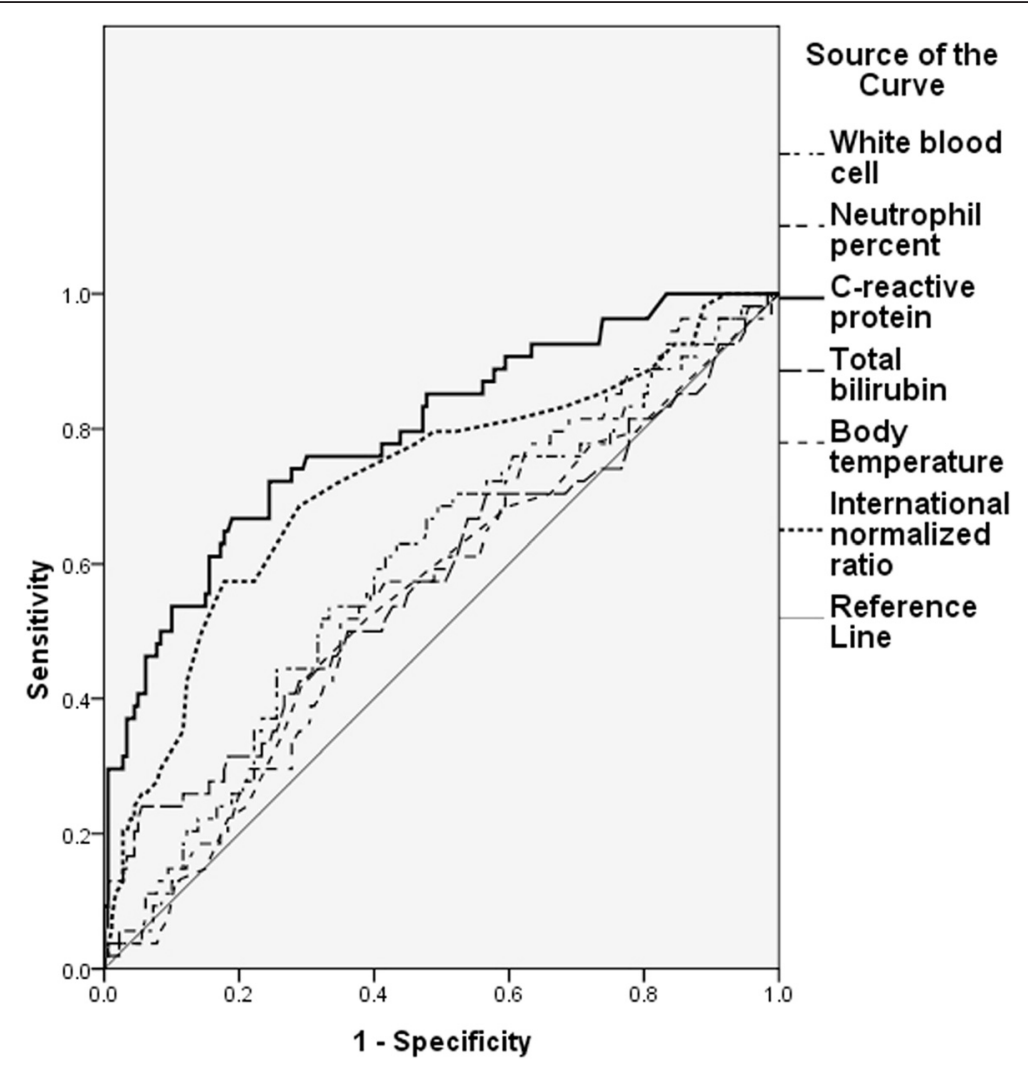

Fig. 1 Receiver operating characteristic (ROC) curve for initial laboratory parameters. The area under the ROC curve of CRP and INR was 0.796 and 0.723 , respectively 
Table 3 Analysis of clinical outcomes and laboratory findings

\begin{tabular}{|c|c|c|c|c|}
\hline & & $\begin{array}{l}\text { Normal CRP } \\
(n=56)\end{array}$ & $\begin{array}{l}\text { Elevated CRP } \\
(n=178)\end{array}$ & p-value \\
\hline Hospital stay (days) & & $3.20 \pm 0.84$ & $3.94 \pm 1.29$ & $<0.001$ \\
\hline \multirow[t]{3}{*}{ Wound complication } & No & 47 (83.9 \%) & 164 (92.1%) & 0.072 \\
\hline & Yes & $9(16.1 \%)$ & $14(7.9 \%)$ & \\
\hline & & $\begin{array}{l}\text { Normal INR } \\
(n=221)\end{array}$ & $\begin{array}{l}\text { Elevated INR } \\
(n=13)\end{array}$ & p-value \\
\hline Hospital stay (days) & & $3.70 \pm 1.18$ & $4.85 \pm 1.68$ & 0.001 \\
\hline \multirow[t]{2}{*}{ Wound complication } & No & 200 (90.5 \%) & $11(84.6 \%)$ & 0.072 \\
\hline & Yes & 21 (9.5 \%) & $2(15.4 \%)$ & \\
\hline
\end{tabular}

$C R P$ serum $C$-reactive protein, INR international normalized ratio, $n$ number of patients

One more point to consider is the cost of each marker. INR costs $2.03 \$$ per test which is much cheaper than CRP (7.82 \$ per test), as per the national health insurance system. Although CRP showed better AUC value, cost-effectiveness should be evaluated in further studies.

We also analyzed post-operative outcomes. Previous studies showed that CA was associated with poorer post-postoperative outcomes [24-26]. Elevated INR and CRP were associated with longer hospital stay; however, no statistical correlation with wound complication was identified. To clarify this association, further studies analyzing postoperative outcome are required.

Additionally, further studies looking at the choice of the management strategy for acute appendicitis according to laboratory findings are required. Proper selection of patients with NA who have normal INR or CRP for conservative management will help to validate conservation, hence avoiding unnecessary appendectomies. Our study may serve as the base for these future studies.

Other limitations of our study include the small sample size and the retrospective single center design. Large-scaled, multicenter-based studies are needed to further elucidate our findings.

\section{Conclusions}

In conclusion, elevated INR and CRP were associated with complicated appendicitis and longer hospital stay. Further studies relating laboratory findings and outcomes of conservative management are required.

\section{Abbreviations}

BT, body temperature; CA, complicated appendicitis; CRP, serum C-reactive protein; INR, international normalized ratio; NA, non-complicated appendicitis; TB, total bilirubin; WBC, white blood cell counts.

Acknowledgement

Not applicable.
Funding

There was no financial or other type of support.

Availability of data

The data will not be shared because of further study plan.

Authors' contributions

MK was involved in study conception, design, analysis, interpretation, and writing of the manuscript; SK was involved in study conception, acquisition of data, interpretation, and revision; HC was involved in study conception, acquisition of data, design, analysis, interpretation, and writing of the manuscript. All authors read and approved the final manuscript.

\section{Competing interests}

The authors declare that they have no competing interests.

Consent for publication section

Not applicable.

Ethics approval and consent to participate

Institutional review board of Uijeongbu St. Mary's hospital approved this retrospective study and informed consent was waived.

Received: 28 February 2016 Accepted: 25 May 2016

Published online: 21 June 2016

References

1. Lee JH, Park YS, Choi JS. The epidemiology of appendicitis and appendectomy in South Korea: national registry data. J Epidemiol. 2010;20:97-105.

2. D'Souza N. Appendicitis. BMJ Clin Evid. 2011;2011.

3. Noh H, Chang SJ, Han A. The diagnostic values of preoperative laboratory markers in children with complicated appendicitis. J Korean Surg Soc. 2012;83:237-41.

4. Li X, Zhang J, Sang L, Zhang W, Chu Z, Li X, et al. Laparoscopic versus conventional appendectomy-a meta-analysis of randomized controlled trials. BMC Gastroenterol. 2010;10:129.

5. Masoomi H, Nguyen NT, Dolich MO, Mills S, Carmichael JC, Stamos MJ. Laparoscopic appendectomy trends and outcomes in the United States: data from the Nationwide Inpatient Sample (NIS), 2004-2011. Am Surg. 2014;80:1074-7.

6. Grande M, Lisi G, Bianchi D, Bove P, Miano R, Esser A, et al. Bilateral ureteral obstruction in children after appendectomy. Case Rep Surg. 2015;2015:740795.

7. Rajan M, Dip F, Szomstein S, Zanghi A, Cavallaro A, Di Vita M, et al. Staple line as a cause of unusual early internal hernia after appendectomy. Int J Surg. 2014;12 Suppl 1:S159-61.

8. Andersson MN, Andersson RE. Causes of short-term mortality after appendectomy: a population-based case-controlled study. Ann Surg. 2011;254:103-7.

9. Rocha LL, Rossi FM, Pessoa CM, Campos FN, Pires CE, Steinman M. Antibiotics alone versus appendectomy to treat uncomplicated acute appendicitis in adults: what do meta-analyses say? World J Emerg Surg. 2015;10:51.

10. Tanaka Y, Uchida H, Kawashima H, Fujiogi M, Takazawa S, Deie K, et al. Long-term outcomes of operative versus nonoperative treatment for uncomplicated appendicitis. J Pediatr Surg. 2015;50:1893-7.

11. Kelly ME, Khan A, Ur Rehman J, Waldron RM, Khan W, Barry K, et al. A national evaluation of the conservative management of uncomplicated acute appendicitis: how common is this and what are the issues. Dig Surg. 2015;32:325-30.

12. Kim TH, Cho BS, Jung JH, Lee MS, Jang JH, Kim CN. Predictive factors to distinguish between patients with noncomplicated appendicitis and those with complicated appendicitis. Ann Coloproctol. 2015;31:192-7.

13. Sandstrom A, Grieve DA. Hyperbilirubinaemia: its utility in non-perforated appendicitis. ANZ J Surg. 2015. doi:10.1111/ans.13373.

14. Adams HL, Jaunoo SS. Hyperbilirubinaemia in appendicitis: the diagnostic value for prediction of appendicitis and appendiceal perforation. Eur $J$ Trauma Emerg Surg. 2015. doi:10.1007/s00068-015-0540-x.

15. Atema JJ, van Rossem CC, Leeuwenburgh MM, Stoker J, Boermeester MA. Scoring system to distinguish uncomplicated from complicated acute appendicitis. Br J Surg. 2015;102:979-90. 
16. Tsukada K, Miyazaki T, Katoh H, Masuda N, Ojima H, Fukuchi M, et al. CT is useful for identifying patients with complicated appendicitis. Dig Liver Dis. 2004;36:195-8

17. Foley TA, Earnest 4th F, Nathan MA, Hough DM, Schiller HJ, Hoskin TL. Differentiation of nonperforated from perforated appendicitis: accuracy of CT diagnosis and relationship of $C T$ findings to length of hospital stay. Radiology. 2005;235:89-96.

18. Griffey RT, Sodickson A. Cumulative radiation exposure and cancer risk estimates in emergency department patients undergoing repeat or multiple CT. AJR Am J Roentgenol. 2009;192:887-92.

19. Shah KH, Slovis BH, Runde D, Godbout B, Newman DH, Lee J. Radiation exposure among patients with the highest $\mathrm{CT}$ scan utilization in the emergency department. Emerg Radiol. 2013;20:485-91.

20. Panagiotopoulou IG, Parashar D, Lin R, Antonowicz S, Wells AD, Bajwa FM, et al. The diagnostic value of white cell count, $C$-reactive protein and bilirubin in acute appendicitis and its complications. Ann R Coll Surg Engl. 2013:95:215-21.

21. McGowan DR, Sims HM, Zia K, Uheba M, Shaikh IA. The value of biochemical markers in predicting a perforation in acute appendicitis. ANZ J Surg. 2013;83:79-83.

22. Grignani G, Maiolo A. Cytokines and hemostasis. Haematologica. 2000;85:967-72

23. Levi M, Toh CH, Thachil J, Watson HG. Guidelines for the diagnosis and management of disseminated intravascular coagulation. British Committee for Standards in Haematology. Br J Haematol. 2009;145:24-33.

24. Kelly ME, Khan A, Riaz M, Bolger JC, Bennani F, Khan W, et al. The utility of neutrophil-to-lymphocyte ratio as a severity predictor of acute appendicitis, length of hospital stay and postoperative complication rates. Dig Surg. 2015;32:459-63.

25. Chen CC, Ting CT, Tsai MJ, Hsu WC, Chen PC, Lee MD, et al. Appendectomy timing: Will delayed surgery increase the complications? J Chin Med Assoc. 2015;78:395-9.

26. Kim MS, Park HW, Park JY, Park HJ, Lee SY, Hong HP, et al. Differentiation of early perforated from nonperforated appendicitis: MDCT findings, MDCT diagnostic performance, and clinical outcome. Abdom Imaging. 2014;39:459-66.

\section{Submit your next manuscript to BioMed Central and we will help you at every step:}

- We accept pre-submission inquiries

- Our selector tool helps you to find the most relevant journal

- We provide round the clock customer support

- Convenient online submission

- Thorough peer review

- Inclusion in PubMed and all major indexing services

- Maximum visibility for your research

Submit your manuscript at www.biomedcentral.com/submit 